\title{
Polska szkoła reportażu w świecie. Uwagi wstępne
}

\section{Polish School of Reportage in the World: Introductory Remarks}

Dziennikarstwo literackie ma w Polsce ogromną tradycję, o czym świadczy monumentalna publikacja: 100/XX + 50. Antologia polskiego reportażu. Autor wyboru Mariusz Szczygieł określa reportaż jako „dobro narodowe Polski”. Pierwszym i największym ambasadorem polskiego reportażu literackiego poza granicami kraju był Ryszard Kapuściński. Od czasu publikacji Cesarza i jego kolejnych książek czytelnicy z całego świata zetknęli się z potęgą literackiej tradycji, której początki są odległe. Niemniej śmierć legendarnego korespondenta wcale nie wpłynęła na osłabienie nurtu, wręcz przeciwnie - w ostatnich latach polska szkoła reportażu okazała się niezwykle żywotna. Stało się to między innymi dzięki staraniom „Gazety Wyborczej” (dowartościowanie działu „reportaż”), wydawnictwa Czarne oraz innych oficyn, które publikują co roku dziesiątki nowych książek tak zwanej literatury faktu. Jeszcze innym wskaźnikiem dobrej formy polskiego reportażu literackiego jest ogromna liczba tłumaczeń polskich pisarzy „non-fiction” na wiele języków. Hanna Krall, Jacek Hugo-Bader, Wojciech Jagielski, Mariusz Szczygieł, Artur Domosławski, Wojciech Tochman i inni cieszą się rosnącą popularnością w różnych krajach. Można odnieść wrażenie, że ostatnio polska szkoła reportażu zyskuje osobne miejsce obok francuskiej, brytyjskiej i amerykańskiej jako tradycja ważna dla literackiego dziennikarstwa.

W tym numerze zaprosiliśmy do współpracy znawców polskiego reportażu z Polski i zagranicy, którym postawiliśmy kilka pytań:

1. Jaka jest ranga polskiej szkoły reportażu w świecie? Jakie są jej najważniejsze cechy?

2. Czy polski reportaż jest rozpoznawalny na tle międzynarodowym?

3. Co sprawia, że anglojęzycznego czytelnika (i wydawcę) bardziej interesuje to, co pisze o Afryce, Afganistanie czy Rosji polski reporter niż jego rodak, z którym dzieli ten sam mainstreamowy światopogląd? 
4. Dzięki czemu polska szkoła reportażu trafia do obiegu międzynarodowego - czy to kwestia stylu, udoskonalenia gatunku w rodzimej tradycji?

5. Co wpłynęło na uformowanie cech, stylu polskiego reportażu? Czy te same czynniki naznaczyły inne tradycje dziennikarskie: amerykańską, angielską czy francuską?

6. Którzy polscy reporterzy są najpopularniejsi w kraju? Czy hierarchia ta pokrywa się z ich odbiorem zagranicznym?

7. Jaki jest wpływ Kapuścińnkiego na dalsze losy szkoły polskiej?

W odpowiedzi na powyższe pytania otrzymaliśmy artykuły wybitnych polskich i zagranicznych specjalistów w zakresie literackiego reportażu. Blok główny rozpoczynamy od tekstu Urszuli Glensk i Milana Lesiaka (Mozaikowanie prawdy. Narracje quasi-faktyczne $w$ reportażu literackim), którzy wprowadzają kategorie „narracji quasi-faktycznej” oraz „narracji faktoidalnej”. Ta propozycja teoretyczna została omówiona na przykładzie twórczości autorów dawnych i współczesnych, takich jak Melcer, Wańkowicz, Krall, Kaszuba-Dębska, Jagielski czy Fryczkowska.

Następnie wyruszamy w podróż do różnych zakątków świata, aby zobaczyć, jakie jest miejsce polskiej szkoły reportażu na globalnej scenie. Zaczynamy od panoramicznego ujęcia Marii Zadenckiej, Polski reportaż $w$ Szwecji, w którym przywołane są trzy prace doktorskie obronione na uczelniach szwedzkich (Jungstrand, Pluwak, Aare). Dotyczą one gatunku reportażu i zawierają między innymi analizy tekstów - Krall, Kapuścińskiego, Tochmana i Hugo-Badera.

Później zaglądamy do Czech. Michala Benešová w tekście Kilka uwag na temat czeskiej recepcji polskiej tradycji reportażowej analizuje, które polskie reportaże ukazują się w czeskich przekładach, jak są one odbierane i jaki obraz polskiego reportażu wyłania się z takiej recepcji.

Potem przenosimy się do świata hiszpańskojęzycznego, gdzie przyglądamy się recepcji Kapuścińskiego, uważanego w pewnych kręgach za niemal króla dziennikarstwa. Zaczynamy od artykułu Małgorzaty Kolankowskiej Tropem Kapuścińskiego w Hiszpanii - o poszukiwaniu odniesień oraz dziennikarskich inspiracji, który skupia się na źródłach fascynacji twórczością polskiego reportera w hiszpańskim środowisku akademickim. Autorka wskazuje, że refleksje Kapuścińskiego na temat zawodu reportera i korespondenta są wciąż aktualne, a wielu hiszpańskich dziennikarzy wprost lub pośrednio odwołuje się do nich w swojej pracy. Następnie Aleksandra Wiktorowska - w tekście Ryszard Kapuśsiński w Hiszpanii i Ameryce Eacińskiej - przedstawia losy potężnej recepcji „Kapu” w tamtym obszarze językowo-kulturowym, posługując się klasyczną metodą Jaussa, a ostatecznie stara się wyjaśnić, dlaczego dzieła Kapuścińskiego zdobyły rozgłos właśnie pod tymi szerokościami geograficznymi. Z kolej Amelia Serraller Calvo w swoim szkicu Ryszard Kapuścinski and the Fierce Debate on "Magical Journalism" zastanawia się nad słusznością pojęcia „magiczne dziennikarstwo”, które stosowane jest w odniesieniu do polskiego reportera i jego przyjaciela Gabriela Garcíi Márqueza, i szuka - jakby w odwrotnym kierunku aniżeli poprzednie dwie badaczki źródeł inspiracji dla Kapuścińskiego w literaturze latynoamerykańskiego boomu. 
W dalszej części znajdziemy teksty dotyczące wielkich reporterów współczesnych, których książki przekraczały granice Polski. W artykule „Белая горячка” $i$ „White Fever". Jak za granica (nie) czytaja Jacka Hugo-Badera Izabella Adamczewska-Baranowska analizuje zagraniczną recepcję książek reporterskich $\mathrm{Hu}$ go-Badera o byłym ZSRR, które na rynku amerykańskim klasyfikowane są jako survival non-fiction, a w Europie Wschodniej budzą ambiwalentne reakcje. Proponowane case study $\mathrm{w}$ szerszej perspektywie wskazuje na różne możliwości funkcjonowania polskich reportaży za granicą. Dzięki Monice Wiszniowskiej wrócimy do Szwecji. W swoim szkicu „Dom z dwiema wieżami” Macieja Zaremby Bielawskiego jako ,arcypolska opowieść reporterska napisana po szwedzku” przygląda się ona oddziaływaniu cech polskiej szkoły reportażu na twórczość szwedzkiego publicysty polskiego pochodzenia, skupiając się na jego ostatniej książce, która w 2018 roku zdobyła Nagrodę im. Ryszarda Kapuścińskiego. Z kolei Wyklęcie Papuszy wedtug Angeliki Kuźniak, czyli biograficzny reportaż jako esej autorstwa niżej podpisanego proponuje lekturę książki Kuźniak o tragicznym losie cygańskiej poetki Papuszy jako podtekstowy esej o różnych wykluczeniach (począwszy od genderowych). Sugeruję w nim, że właśnie eseistyczny charakter tego reportażu stanowi o jego uniwersalizmie i atrakcyjności poza granicami polskiej (i romskiej) kultury.

Zamykamy blok główny, wracając w rozmowie Ryszard Kapuściński i polski reportaz $w$ oczach ttumaczy do największego ambasadora polskiej szkoły reportażu w świecie. Odpowiadając na moje pytania, dwie renomowane tłumaczki, Agata Orzeszek i Vera Verdiani, które przełożyły niemal całą twórczość pisarza z Pińska, współdzielą się anegdotami, informacjami i rozmyślaniami dotyczącymi historii recepcji twórczości Kapuścińskiego i polskiego reportażu w obszarze języka hiszpańskiego i włoskiego.

W numerze znalazły się także teksty o wydawniczych nowościach. Danuta Sosnowska podejmuje dialog z dwutomową publikacją Literatura a religia. Wyzwania epoki świeckiej, Łukasz Wróbel wskazuje na atuty i słabości dwutomowej biografii Romana Ingardena. W dziale recenzji z kolej Michał Masłowski pisze o studium Larry'ego Wolffa Wynalezienie Europy Wschodniej. Mapa cywilizacji $w$ dobie Oświecenia, a Agnieszka Bielak omawia książkę Piotra Mitznera Ludzie z nieludzkiej ziemi. Rosyjski krag Józefa Czapskiego.

Pau Freixa Terradas

Uniwersytet Barceloński Redaktor prowadzacy zeszytu 